\title{
Current state, habitat and potential invasiveness of Montia linearis (Douglas ex Hook.) Greene in Poland
}

\author{
Iwona Dembicz ${ }^{1 *}$, Łukasz Kozub1 ${ }^{1}$ Piotr T. Zaniewski ${ }^{2}$ \\ 1 Department of Plant Ecology and Environmental Conservation, Institute of Botany, Faculty of Biology, University of Warsaw, Żwirki i Wigury 101, 02-089 Warsaw, Poland \\ ${ }^{2}$ Department of Forest Botany, Faculty of Forestry, Warsaw University of Life Sciences - SGGW, Nowoursynowska 159, 02-776 Warsaw, Poland
}

\begin{abstract}
Montia linearis is a vascular plant originating from western North America. The expansion of this species has been observed for several decades. For the first time M. linearis was found in Europe in 1989. Further six populations were documented by 2004 within the continent: three in Poland, two in Denmark and one in Hungary.

Apart from discovering a new population of $M$. linearis, we confirmed two out of the three previously known localities of the species in Poland. All the currently known populations of M. linearis occupied predominantly meadow habitats, especially intensively managed sites. Some individuals were also found in disturbed sites with bare soil. The studied species inhabited soils of various types with broad range of fertility as well as humidity. Montia linearis populations reached densities up to 87 individuals per $0.04 \mathrm{~m}^{2}$. The number of seeds produced by an individual was between 10 and 55 in $90 \%$ of the studied specimens, however much more fertile specimens were also observed.

As the previously presented hypothesis of $M$. linearis dispersal with rail transport seemed not to be well supported, the connection between the $M$. linearis presence and cattle husbandry is considered. It is possible that the species can be transferred with living animals or manure.

The species was able to survive for at least 26 years within once inhabited site. Further spread of $M$. linearis within Europe is highly probable. The aim of the study is to: (i) describe the current state of populations of $M$. linearis in Poland, (ii) provide information on habitat preferences and biology of the species, (iii) assess the invasiveness potential of M. linearis in Poland.
\end{abstract}

Keywords: weed dispersal; intensive agriculture; cattle breeding; meadow; Claytonia linearis; non-native species

\section{Introduction}

At present biological invasions are one of the major environmental threats, not only to biodiversity, but also to human economy [1,2]. In Poland 1017 alien plant species have been observed up to date [3]. Among them, more than 300 are considered to be naturalized alien species introduced after the year 1492 with different degree of invasiveness. This number will probably be growing in the future as a result of new introductions and due to changes of status of other alien plant species already occurring in Poland. The latter relates mainly to casual alien plants (for nomenclature see $[4,5])$ that will become established.

Casual alien plants constitute the largest group of all alien plants in Poland - their number is estimated at 511 species [5]. Species with such status in flora do not form self-sustaining populations. They are not able to persist in the environment for a longer time ( $>10$ years proposed by

*Corresponding author. Email: i.dembicz@biol.uw.edu.pl

Handling Editor: Zygmunt Kącki
Richardson et al. [6] or $>25$ years by Tutin et al. [7]) without the anthropogenic "supply" of propagules.

However, the status of the species in the flora can change. This can happen due to the evolutionary change of the species, environmental changes (e.g., climate change) or as a result of long-term observations in the case of species classified firstly as casual alien plant, but in fact creating self-sustaining populations, which cannot be proven during a single observation $[5,6]$. Unequivocal assignment of status to the particular species poses many difficulties since there are no strict borders between "casual - naturalized" and "naturalized - invasive" species status, as it is rather a continuum [6]. However, monitoring of non-invasive alien plants and detection of some population trends towards invasiveness at very early stages could be important, as fighting an invasion is much easier if it has started at its beginning, when the invading species is still not common [8].

Montia linearis (Douglas ex Hook.) Greene [syn. Claytonia linearis Douglas ex Hook., Montiastrum lineare (Dougl. ex Hook.) Rydb.] is an annual, flowering plant belonging to the family Montiaceae (previously to Portulacaceae [9]). It has erect, branched or simple stems $2-30 \mathrm{~cm}$ tall and 
alternate leaves with linear blades measuring up to $10 \mathrm{~cm}$ in length (Fig. 1). The inflorescence of this species is a raceme with small, mainly self-fertilized white flowers. The fruit is a capsule containing up to 3 roundish seeds [10].

The natural distribution of $M$. linearis includes western North America, where it naturally grows in moist habitats, mainly in mountainous areas within a number of habitat types, including, e.g., meadows, river plains, muddy riverbanks, fields, open woodlands and swales within prairies [11-13]. In the early 1970 s the expansion of M. linearis was observed on anthropogenically-altered sites and in lower elevations around the primary range of the species [14]. In the late 1980s the first cases of long-distance dispersion were observed in the eastern states of the USA [13,15] as well as in Europe [16]. Nowadays wild M. linearis populations outside its native range are known from seven states in the south-eastern United States [17] and from three countries in Europe: Poland, Denmark [18,19] and Hungary [20].

The first finding of M. linearis in Poland (and thereby in Europe) was made near the village of Czachówek (vicinities of Góra Kalwaria near Warsaw) in 1989 [16]. The second locality was discovered in the valley of the Bug River in Wyszków [21] and the third one was found in 2002 by Bińka (herbarium KRA) near the village of Krzymosze (in the vicinity of Siedlce, east-central Poland). Besides the distribution characteristics our knowledge about the ecology of the species in Poland is still insufficient. The database Alien Species in Poland created by Institute of Nature Conservation [22] contains no data on the population dynamics, as well as on the suggested control methods of the species. Regular monitoring of $M$. linearis and investigation of some aspects of its ecology are essential to prevent the negative effects of its possible further expansion.

The main aim of this study was to assess the status and potential invasiveness of $M$. linearis in Poland. The assessment was based on the description of a newly discovered locality of $M$. linearis in the country, description of the current state of its populations in all of the known Polish localities and additional information on habitat preferences and biology of the species.

\section{Material and methods}

The field studies were carried out in early spring 2011 and 2014. In April 2011 a new locality of M. linearis was discovered on the meadow near Sochocin. Soon after (April and May 2011) the search for this species was conducted in two other previously known localities: near Czachówek and in Wyszków. The species was confirmed to occur only at the former locality. In April and early May 2014 all the above-mentioned sites were investigated again. This time the locality near Krzymosze was also checked. The occurrence of $M$. linearis populations was confirmed in three localities: near Sochocin, Czachówek and Krzymosze (Fig. 2). All the sites were carefully searched for the species and the land use types were noted. All the fieldwork was performed using GPS receiver.

Within all the investigated localities three to four $16 \mathrm{~m}^{2}$ plots with considerable share of $M$. linearis were selected

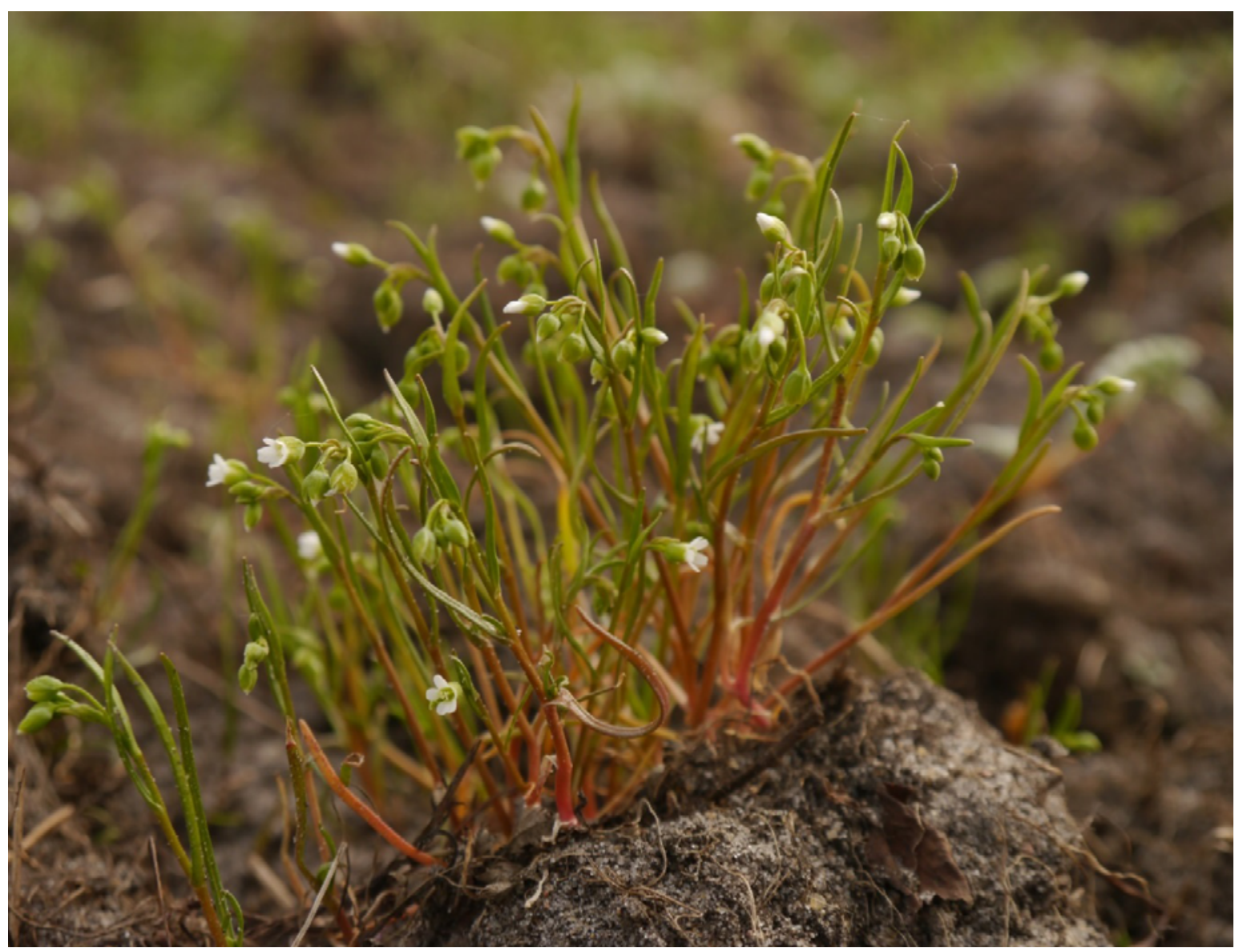

Fig. 1 Flowering Montia linearis, Czachówek, 2014.04.25. Photo: I. Dembicz. 

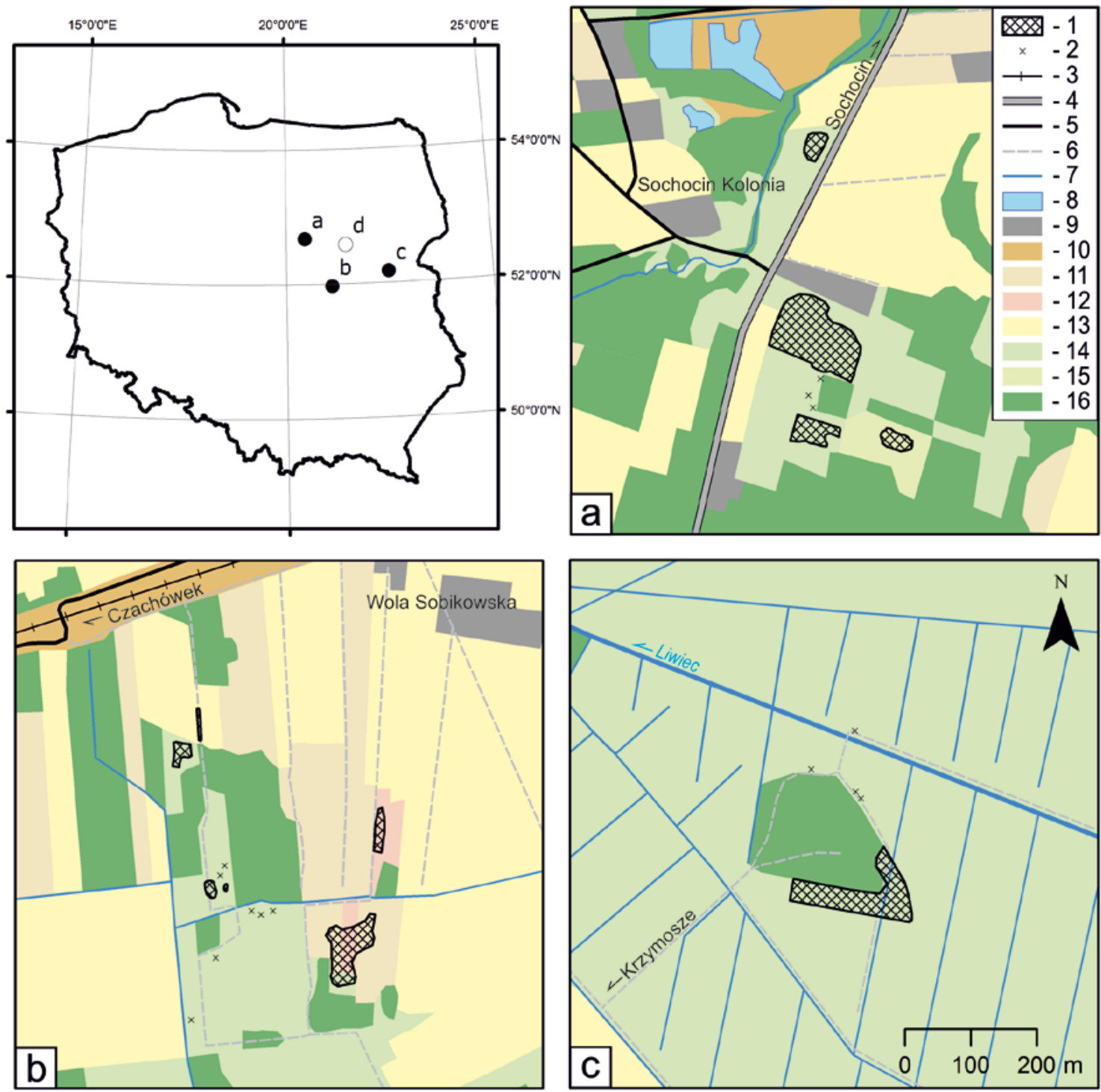

Fig. 2 Distribution of Montia linearis in Poland: confirmed localities in the vicinities of: Sochocin (a), Czachówek (b) and Krzymosze (c) and unconfirmed (probably extinct) population in Wyszków (d). 1 - dense populations of M. linearis; 2 - single individuals of $M$. linearis; 3 - railway track; 4 - national road; 5 - local asphalt roads; 6 - dirt roads; 7 - watercourses; 8 - water bodies; 9 - settlements; 10 - wastelands; 11 - fallows; 12 - plowed fallows; 13 - cultivated fields; 14 - meadows; 15 - pastures; 16 - forests/thickets.

(altogether 10 plots). Relevés were taken within sampling plots using modified Braun-Blanquet scale [23] for coverage estimations in order to characterize the vegetation types occupied by the species. The taxa of vascular plants and mosses were distinguished according to Mirek et al. [24] and Hill et al. [25] respectively. Syntaxa were described according to Matuszkiewicz [26]. In order to investigate the environmental conditions from each plot a soil sample was collected (mixed sample from five random places within a plot, from the depth of 5-10 cm). Subsequently the samples were air-dried. The sieve analysis (according to the norm BN-78/9180-11), as well as $\mathrm{pH}$ measurements in the water and in the $1 \mathrm{M} \mathrm{KCl}$ solution were conducted. The Ellenberg's indicator values [27] were used to obtain the information about general fertility and moisture of the habitat within the plots. For each relevé weighted means of the values were calculated. The ranks of coverage were converted into percentage scale as follows: $r=0.1 \%$, “+” $=0.5 \%, 1=2.5 \%$, $2 \mathrm{a}=8.5 \%, 2 \mathrm{~b}=18.5 \%, 3=37.5 \%, 4=62.5 \%$.

In eight of the above mentioned plots (Nos. 1-3 and 6-10) all the individuals of $M$. linearis within six square $0.04 \mathrm{~m}^{2}$ subplots were counted to obtain information about the maximum density of its populations. The subplots were selected non-randomly - within the highest visible densities of the studied species. Twelve individuals from each of the populations were transplanted to an experimental garden (standard, commercially available horticultural substrate) and grown in order to estimate the average number of seeds produced by a single individual. The transplantation method was considered better than study on site due to the seasonal ephemerality of the species, the unpredictability of its phenology (especially the end of flowering) and problems with its finding in the dense meadow vegetation at the time of seed shedding at the end of May. 


\section{Results}

\section{Characteristics of the current localities}

All the studied populations of $M$. linearis were distributed within areas used for agriculture (Fig. 2). The size of each population was estimated at several thousand individuals. The distribution of $M$. linearis near Sochocin was strictly limited to two intensively managed and overseeded meadows and one pasture, where the studied populations covered together a total of about $1.4 \mathrm{ha}$. It should be noted that near the location of relevé No. 2 (within the pasture) in 2011 there was a large pile of cow manure. In 2014 a dense stand of $M$. linearis was observed at that particular place. The total cover of the population near Czachówek was smaller than in the two other localities - about 0.8 ha, but the species was more dispersed in the landscape. The most distant individuals from the aforementioned population were spaced about $500 \mathrm{~m}$ from one another. Apart from the three intensively managed (fertilized with cow manure) meadows the species also occurred on dirt roads along a cropfield, as well as within fallows and highly disturbed places (plowed fallows and places rooted by a wild boar). Near Krzymosze the individuals of the species were quite evenly scattered on one intensively managed hay meadow (probably fertilized with cow manure) in the area of about 1.5 ha. Three smaller patches with individuals of $M$. linearis $\left(1-5 \mathrm{~m}^{2}\right)$ were also observed along dirt roads in the vicinity of that meadow.

\section{Ecology and morphology}

In areas with developed vegetation cover M. linearis occurred within relatively species poor patches of vegetation from the class Molinio-Arrhenatheretea (Tab. 1). The differences in vegetation between the localities were not very pronounced, however some moisture gradient as well as fertility gradient within the localities could be observed according to mean Ellenberg's indicator values (Tab. 2). In some patches (as within relevés No. 2, 8, 9, 10) M. linearis coexisted with species typical of the order Agropyro-Rumicion crispi, while in other sites it co-occurred with species of more xeric habitats (as within relevé No. 1). Montia linearis occurred mainly on mineral soil (fine or medium sand and loamy sand), but in one case it grew on organic substrate (mineralized peat; Tab. 2). The $\mathrm{pH}$ of the soil varied from 4.09 to 7.08 in $\mathrm{H}_{2} \mathrm{O}$ and from 4.08 to $6.25 \mathrm{in} \mathrm{KCl}$ solution (Tab. 2).

The highest density of the individuals within sampling subplots $0.04 \mathrm{~m}^{2}$ was observed in population near Czachówek (Tab. 3). Within Krzymosze population the observed maximum densities were lower than in Czachówek (reaching only about $1 / 6$ of the density noted in the latter population) (Tab. 3). The number of seeds per single plant (grown in the experimental garden) varied from 10 to 353 (median = 36.5; Tab. 3), however, more than 55 seeds per plant were recorded only in case of three individuals. Most of the plants had $1-6$ branches per one individual $($ mode $=4)$ but in two cases within the population from Sochocin the number was much higher reaching 12 and 25 branches. The potential seed rain from area of $0.04 \mathrm{~m}^{2}$ densely covered with $M$. linearis individuals could reach 3175.5 seeds taking into account maximum measured density of plants (87) and median of seed production per plant (36.5) as when plants grow in dense stands they do not produce maximum possible seed numbers.

\section{Discussion}

\section{Ecology and morphology}

Our studies indicate that in Poland M. linearis occurs mostly on intensively used, fertilized hay meadows and pastures. The species occurs across a relatively broad moisture gradient, both on mineral and organic substrate and tolerates a wide range of soil acidity and fertility. Probably an extinct population of this species in Wyszków [21] grew on sandy dry grassland from the association Diantho-Armerietum elongatae, therefore the ecological amplitude of $M$. linearis in Poland may be even wider extending to habitats drier and poorer in nutrients than those which were described above. In Denmark the species was found within similar habitat types: dry and wet meadows [18]. The population of M. linearis found in 2004 in Hungary near Szeghalom grew in salt meadow representing the alliance Agrostio stoloniferae-Alopecuretum pratensis [20], which may indicate the resistance of this species to periodic submersion, low aeration of soil and increased salinity of a substrate (Tab. 4).

Semi-natural managed grasslands are thought to be relatively resistant towards alien plants invasions [28] though moderate stress caused by management (mowing or grazing) suppresses predominantly highly competitive invasive plant species such as alien Solidago species in Europe [29]. In case of $M$. linearis the cutting of hay does not harm the species as the whole flowering and fruiting period of the species finishes just before the first hay mowing. Moreover, such management supports the maintenance of the species, by removing litter and preventing natural succession.

At particular locations the density of individuals of M. linearis was very high (Fig. 3) but it generally varied greatly within the area occupied by the studied species. The observed differences might not result from differences in the habitat conditions. Perhaps of greater importance was the competition of $M$. linearis seedlings with other plant species, as well as the distribution of propagules of this annual species.

According to Flora of North America [10] M. linearis is a highly uniform species. In addition, studies of Hungarian population showed that the variation of the morphology of the individual plants within the population was relatively small and the number of shoots with inflorescences per one individual always varied from one to three [20]. Our research indicated that within the studied populations the number of branches per plant and the number of flowers can vary and some individuals can produce several times more seeds and branches than the average (in the extreme case there were 25 shoots with inflorescences and 353 seeds per one plant). The ability of this species to self-propagate is rather small - a mechanism of autochory allows spreading of seeds to a maximum distance of 2 meters from the parent plant [30]. However, taking into consideration the results of our studies the possible "seed rain" within $2 \mathrm{~m}$ radius around a small, dense patch of $M$. linearis individuals could reach several thousands of seeds. 
Tab. 1 Relevés with Montia linearis from the studied populations.

\begin{tabular}{|c|c|c|c|c|c|c|c|c|c|c|}
\hline \multirow{2}{*}{$\begin{array}{l}\text { Population } \\
\text { Relevé/plot number }\end{array}$} & \multicolumn{3}{|c|}{ Sochocin } & \multicolumn{4}{|c|}{ Czachówek } & \multicolumn{3}{|c|}{ Krzymosze } \\
\hline & 1 & 2 & 3 & 4 & 5 & 6 & 7 & 8 & 9 & 10 \\
\hline Date & 2011.05 .03 & 2011.05 .03 & 2014.05.02 & 2011.05 .16 & 2011.05 .16 & 2014.04 .25 & 2014.04 .25 & 2014.05 .11 & 2014.05.11 & 2014.05.11 \\
\hline Area of relevé $\left(\mathbf{m}^{2}\right)$ & 16 & 16 & 16 & 16 & 16 & 16 & 16 & 16 & 16 & 16 \\
\hline Slope $\left(^{\circ}\right)$ & 2 & 0 & 0 & 0 & 0 & 0 & 0 & 1 & 0 & 0 \\
\hline Aspect $\left({ }^{\circ}\right)$ & 90 & - & - & - & - & - & - & 45 & - & - \\
\hline Latidude $\mathbf{N}$ & 52.67760 & 52.67616 & 52.67713 & 51.97013 & 51.96871 & 51.96835 & 51.96666 & 52.17664 & 52.17616 & 52.17435 \\
\hline Longitude E & 20.46030 & 20.46183 & 20.46005 & 21.09930 & 21.10343 & 21.09991 & 21.10325 & 22.47569 & 22.47493 & 22.47518 \\
\hline Altitude (m a.s.l.) & 100 & 101 & 102.5 & 112 & 112.5 & 111.5 & 112.5 & 151.2 & 151.3 & 152 \\
\hline Management & mown & grazed & mown & mown & dirt road & mown & fallow & dirt road & dirt road & mown \\
\hline Cover total (\%) & 95 & 95 & 90 & 95 & 90 & 100 & 70 & 97 & 95 & 80 \\
\hline Cover tree layer (\%) & 0 & 0 & 0 & 0 & 0 & 0 & 0 & 0 & 1 & 0 \\
\hline Cover herb layer (\%) & 90 & 90 & 90 & 95 & 90 & 100 & 70 & 97 & 95 & 80 \\
\hline Cover moss layer (\%) & 10 & 20 & 1 & 10 & 0 & 20 & 10 & 3 & 1 & 4 \\
\hline Cover litter layer (\%) & 10 & 2 & 5 & 5 & 10 & 5 & 90 & 5 & 10 & 3 \\
\hline Cover bare soil (\%) & 0 & 0 & 0 & 0 & 10 & 0 & 0 & 3 & 5 & 20 \\
\hline Number of species & 21 & 24 & 25 & 19 & 20 & 16 & 22 & 21 & 16 & 20 \\
\hline Montia linearis & 3 & 3 & $2 b$ & 3 & + & 4 & 3 & 1 & 1 & 1 \\
\hline
\end{tabular}

ChCl. Molinio-Arrhenatheretea

\begin{tabular}{|c|c|c|c|c|c|c|c|c|c|c|}
\hline Poa pratensis & 3 & . & $2 \mathrm{a}$ & 3 & 3 & 4 & . & $2 \mathrm{~b}$ & 1 & 1 \\
\hline Plantago lanceolata & + & + & 1 & + & 1 & . & $2 b$ & . & . & $2 \mathrm{a}$ \\
\hline Rumex acetosa & + & + & + & + & 1 & $2 b$ & $2 \mathrm{a}$ & + & + & $2 \mathrm{~b}$ \\
\hline Cerastium holosteoides & $2 a$ & . & $2 b$ & . & + & 1 & . & + & + & 1 \\
\hline Alopecurus pratensis & + & 1 & . & . & + & . & . & . & $2 \mathrm{a}$ & $2 \mathrm{~b}$ \\
\hline Holcus lanatus & . & 3 & . & . & $2 \mathrm{a}$ & . & + & . & + & $2 b$ \\
\hline Festuca rubra & . & . & . & . & 1 & . & 1 & . & . & 3 \\
\hline Phleum pratense & 3 & . & . & 3 & . & . & . & . & . & . \\
\hline Trifolium pratense & 1 & . & . & + & . & 1 & . & . & . & . \\
\hline Poa trivialis & . & 3 & . & . & . & . & . & . & . & . \\
\hline Cardamine pratensis & . & $2 \mathrm{a}$ & . & . & . & . & . & . & . & . \\
\hline Ranunculus acris & . & 1 & . & + & + & . & + & . & . & + \\
\hline \multicolumn{11}{|c|}{ ChAll. Arrhenatheretalia } \\
\hline Taraxacum sp. & $2 b$ & + & 1 & $2 \mathrm{a}$ & $2 b$ & $2 \mathrm{a}$ & + & 1 & . & + \\
\hline Trifolium repens & . & 3 & 1 & 1 & 1 & $2 \mathrm{a}$ & . & 4 & . & . \\
\hline Dactylis glomerata & 1 & 1 & $2 \mathrm{a}$ & + & + & . & + & + & + & . \\
\hline Achillea millefolium & $2 \mathrm{a}$ & + & $2 \mathrm{a}$ & . & + & + & + & . & . & . \\
\hline Leontodon autumnalis & . & . & . & . & . & . & 1 & . & . & . \\
\hline
\end{tabular}

Elymus repens

Agrostis stolonifera

$2 b$

Alopecurus geniculatus

Carex hirta

Potentilla anserina

Ranunculus repens 
Tab. 1 (continued)

\section{ChAll. Plantaginetalia majoris}

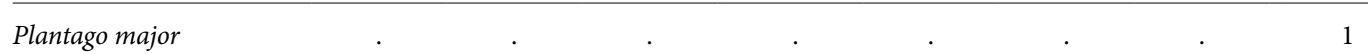

Poa annua

ChAll. Molinietalia

\begin{tabular}{llllllll}
\hline Filipendula ulmaria &. & $\mathrm{r}$ &. &. &. & & \\
Ranunculus auricomus &. & &. &. &. &. &. \\
+
\end{tabular}

ChCl. Koelerio glaucae-Corynephoretea canescentis

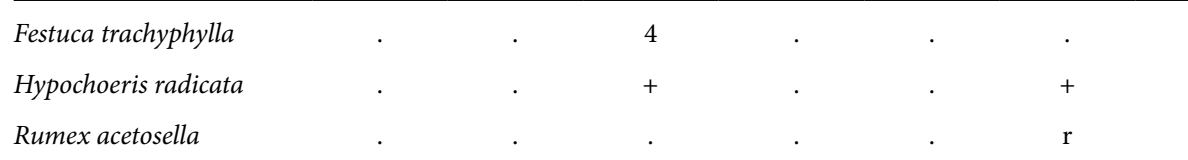

Others

\begin{tabular}{|c|c|c|c|c|c|c|c|c|c|c|}
\hline Alisma plantago-aquatica & . & 1 & . & . & . & . & . & . & . & . \\
\hline Anthoxanthum odoratum & . & + & . & . & . & . & 1 & . & . & 3 \\
\hline Capsella bursa-pastoris & 1 & . & + & . & . & . & . & 1 & . & . \\
\hline Cardaminopsis arenosa & . & . & $\mathrm{r}$ & $\mathrm{r}$ & . & + & 1 & . & . & + \\
\hline Carex nigra & . & . & . & . & . & . & 1 & $\cdot$ & . & . \\
\hline Erodium cicutarium & . & . & 1 & . & . & . & . & . & . & . \\
\hline Galium mollugo & . & . & + & . & . & . & . & . & . & + \\
\hline Luzula campestris & + & + & . & . & $\mathrm{r}$ & . & 1 & . & . & . \\
\hline Phalaris arundinacea & . & . & . & . & . & . & . & + & + & . \\
\hline Polygonum amphibium & . & . & . & . & . & . & . & $\mathrm{r}$ & . & + \\
\hline Stellaria media & . & . & + & . & . & . & . & 1 & . & . \\
\hline Veronica arvensis & + & . & 1 & + & $\cdot$ & + & . & 1 & . & . \\
\hline Veronica chamaedrys & + & + & + & . & $\cdot$ & . & + & . & + & + \\
\hline Viola arvensis & $\cdot$ & . & + & $\mathrm{r}$ & . & . & . & . & . & . \\
\hline Brachythecium sp. d & $2 \mathrm{a}$ & $2 b$ & + & $2 \mathrm{a}$ & . & $2 b$ & $2 \mathrm{a}$ & 1 & + & 1 \\
\hline
\end{tabular}

Sporadic species: Ch. Molinio-Arrhenatheretea: Vicia cracca 8: r; Ch. Arrhenatheretalia: Bellis perennis 2: +; Bromus hordaceus 7: +; Ch. Trifolio fragiferae-Agrostietalia stoloniferae, Agropyro-Rumicion crispi: Lysimachia nummularia 3: +; Rumex crispus 9: +; Ch. Molinietalia: Juncus effusus 3: +; Lysimachia vulgaris 4: r; Symphytum officinale 4: +; Glechoma hederacea 4: +; Ch. Nardo-Callunetea: Agrostis capillaris 5: +; Ch. Koelerio-Corynephoretea: Senecio vernalis 2: r. Others: Anthriscus sylvestris 7: +; Carex panicea 3: +; Geranium pusillum 1: +; Hieracium pilosella 6: +; Juncus articulatus 3: r; Linaria vulgaris 7: +; Luzula multiflora 4: r; Matricaria perforata 2: r; Myosotis stricta 1: +; Prunus padus a 9: +; Urtica dioica 9: +; Senecio jacobaea 2: +; Veronica serpyllifolia 5: +; V. triphyllos 1: +; Vicia sativa 1: +.

Tab. 2 Habitat properties within the studied plots.

\begin{tabular}{lcccccccccc}
\hline Plot No. & $\mathbf{1}$ & $\mathbf{2}$ & $\mathbf{3}$ & $\mathbf{4}$ & $\mathbf{5}$ & $\mathbf{6}$ & $\mathbf{7}$ & $\mathbf{8}$ & $\mathbf{9}$ & $\mathbf{1 0}$ \\
\hline Soil texture & LFS & FS & FS & MS & MS & MS & MS & LFS & - & LFS \\
pH H H & 5.99 & 5.99 & 5.95 & 6.64 & 6.67 & 5.59 & 4.09 & 7.08 & 6.15 & 6.34 \\
$\mathrm{pH} \mathrm{KCl}$ & 4.83 & 5.2 & 4.21 & 5.69 & 5.81 & 4.08 & 4.12 & 6.25 & 5.49 & 5.45 \\
SOM (\%) & 3.87 & 10.16 & 2.53 & 7.92 & 7.88 & 5.12 & 6.66 & 5.11 & 76.07 & 11.42 \\
EIV - N & 6.64 & 5.63 & 3.80 & 6.96 & 7.01 & 7.21 & 4.30 & 5.70 & 6.48 & 5.35 \\
EIV - F & 5.24 & 6.35 & 3.90 & 5.46 & 5.72 & 5.72 & 5.22 & 6.25 & 5.46 & 6.56 \\
\hline
\end{tabular}

Number of plots as given in Tab. 1. Abbreviations of soil texture: FS - fine sand, LFS - loamy fine sand, MS - medium sand; other: SOM - soil organic matter content, EIV - average Ellenberg's indicator values of fertility $(\mathrm{N})$ and moisture (F) of the soil. 


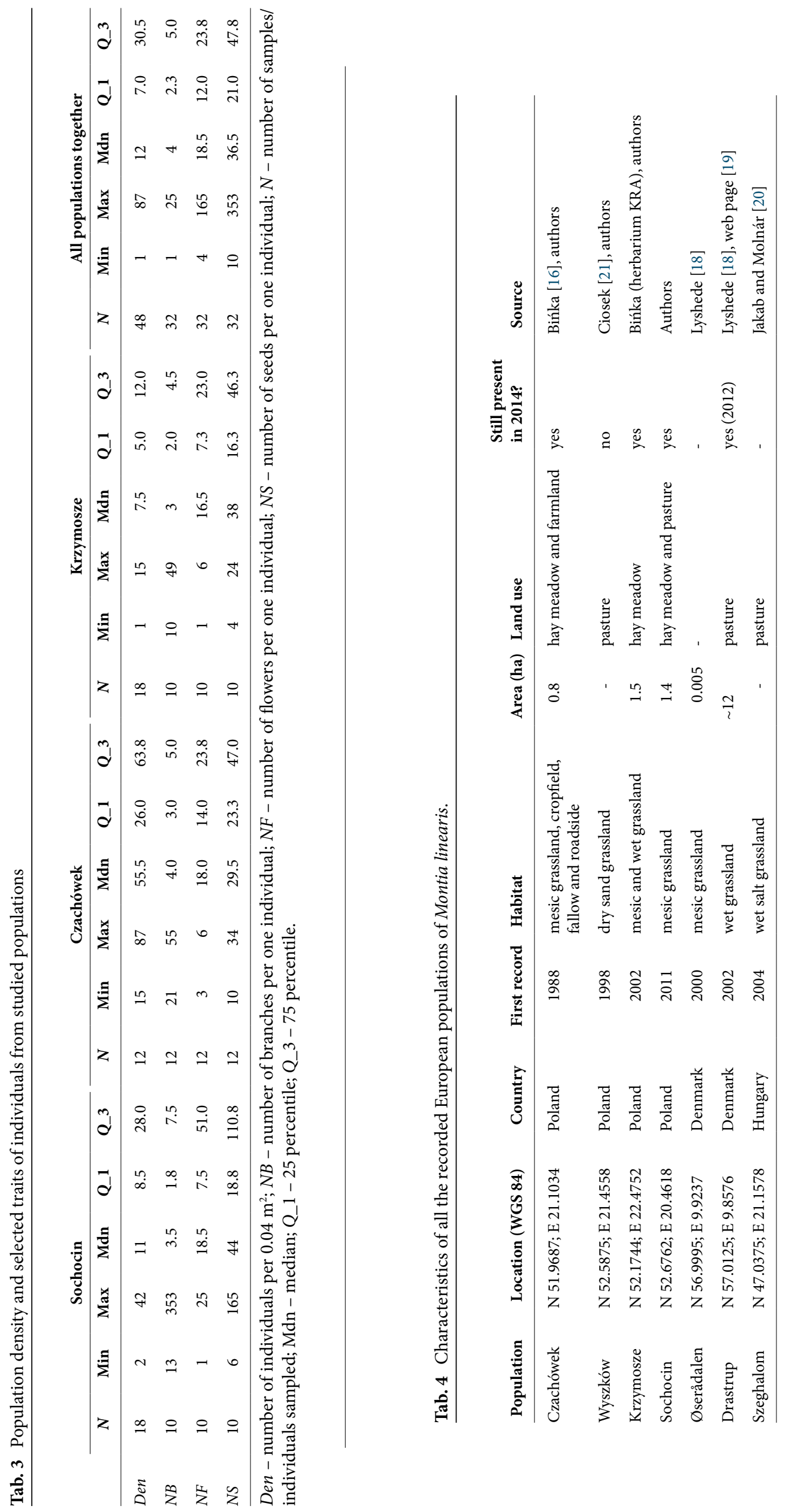




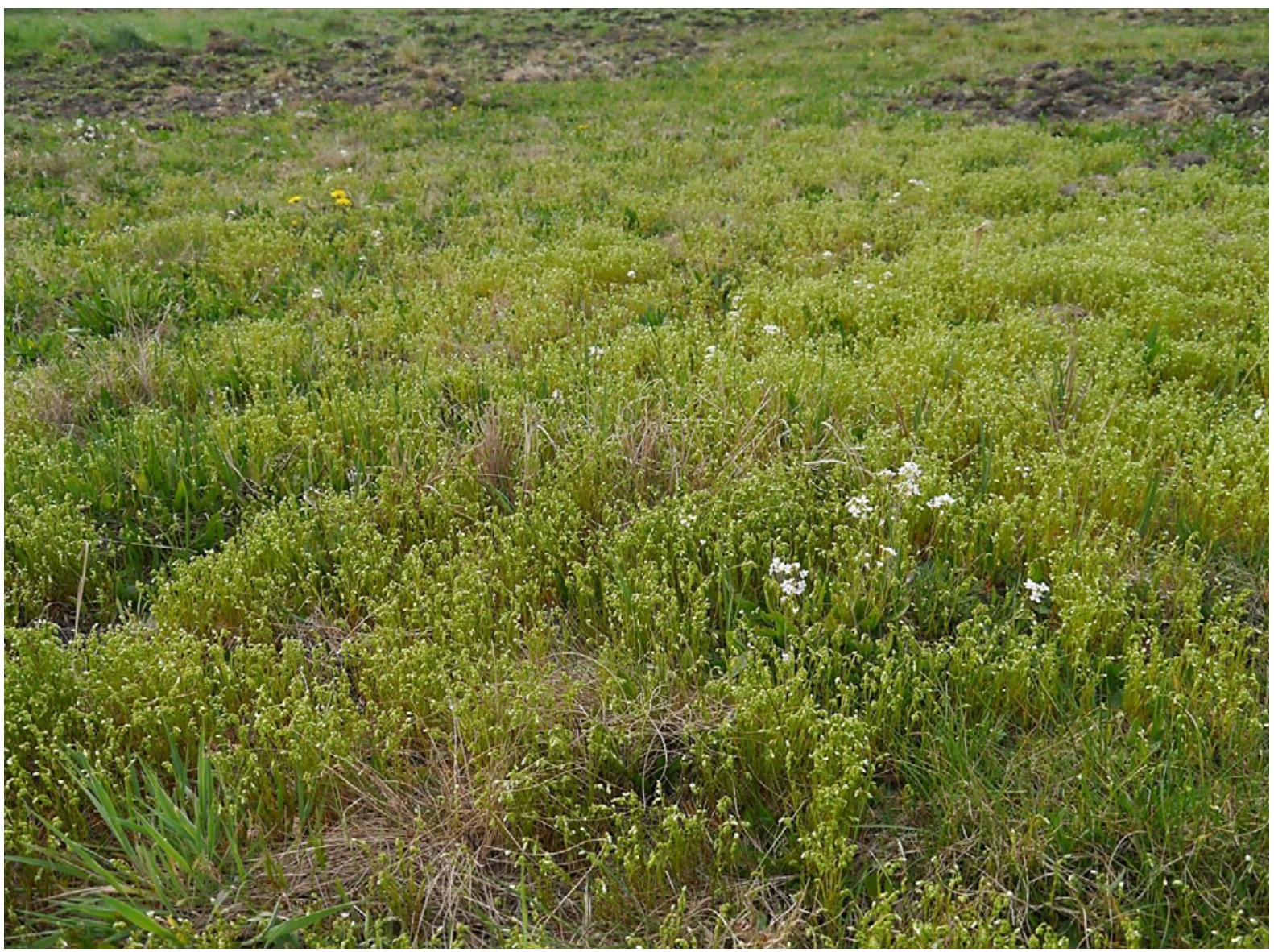

Fig. 3 A patch of vegetation with dense stand of Montia linearis in Czachówek, 2014.04.24. Photo: I. Dembicz.

\section{Hypothetical dispersal vectors}

According to the hypothesis of Bińka [16] rail transport was a long-distance way of $M$. linearis seeds spreading in Europe. In the case of the three initially known localities in Poland such vector of seeds could be somehow justified, as these localities were close to the railroad tracks. However, the next discovered locality of $M$. linearis in Poland, as well as the Hungarian and Danish populations were located far from the railway tracks. The hypothesis presupposed the existence of populations of the species in other parts of Europe or Asia, however so far there have been no such reports. Furthermore, the author [16] did not indicate the initial vector of M. linearis propagules from North America to Europe (or Asia). Jakab and Molnár [20] provide a more convincing hypothesis, according to which the seeds of $M$. linearis were brought with cattle that was imported from North America to Hungary in the 1960s. The authors suggested that the seeds could have been attached to the hoofs of the cows. To date, all the European stands of $M$. linearis have occurred only within agriculturally managed ecosystems. Moreover, the use of these sites is largely associated with cattle breeding. Dispersal of the species by cattle was mentioned by Lyshede [18] in case of one of the Danish populations and described by Jakab and Molnár [20] for the locality in Hungary. Our observations on surveyed locations in Poland also support the hypothesis on association of $M$. linearis populations with cattle husbandry (Tab. 4). It is noteworthy that near the population of M. linearis in Krzymosze there was a large state farm and nowadays cattle breeding is continued in a big, modern farm close to the previous one. Both grazing and application of manure to fertilize the meadows were present in Sochocin. Manuring was also observed in Czachówek. Seed dispersal by cows seems also very probable in the case of dry sandy grassland, inhabited by the population of M. linearis described by Ciosek [21] as this type of vegetation develops as a result of extensive grazing. It is worth noting that within the researched areas groups of individuals were observed along the dirt roads used by farmers as access to the meadows. In addition, the occurrence of the species was often limited by the borders of specific parcels (Fig. 2). The collected data support the hypothesis that dispersion and persistence of $M$. linearis depends somehow on manuring and/or grazing. There are no data in literature concerning the endozoochoric spread of this species, though hard testa, "streamlined" shape of the seeds and their relatively large size could constitute a prerequisite for the adaptation to this type of dispersal. Cattle manure may contain seeds of many species of plants, some of which retain the ability to germinate after passing through the digestive tract of cows [31]. In order to reduce or even eliminate the germination of such propagules the manure had to be properly prepared prior to application in the fields, e.g., by composting [32]. However, it was found that in order to kill the seeds with a thick testa a higher temperature of composting was usually needed. This requires more treatments and work (e.g., aeration and adding water [32,33]). Montia linearis might 
have seeds that are resistant to composting carried out at lower temperatures or its seeds are distributed with fresh manure applied to the meadows where the concern about weed control is much lower than in the case of arable land. The time of fruiting of the species (the end of May/June) coincides with the period of the first hay harvest, which could lead to the seeds being present in the fodder and bedding for cattle. The presented "dispersion cycle" of $M$. linearis within Polish localities is merely hypothetical and for its validation further research is needed.

We have already indicated the possibility of the species to spread along dirt roads with machinery and vehicles that enter the areas inhabited by M. linearis. Such way of dispersion could result in creating other populations in the vicinities of the former ones as the same machinery is often used by other farmers. The role of soil seed bank in the persistence and dispersal of $M$. linearis population in the surveyed locations could not be excluded as well. The closely related species Claytonia ozarkensis forms only a transient seed bank [34], but until now no studies on viability of seeds of $M$. linearis were published.

\section{Status in the Polish flora and potential invasiveness}

Currently, M. linearis is considered to be a casual alien plant in Poland [35]. In the locality in Czachówek the population of this species has existed for at least 26 years, in the locality in Krzymosze at least 12 years and the population near Sochocin has been observed for 4 years. The extinction of the population in Wyszków could be associated with strong mechanical disturbances, e.g., trampling (mentioned by Ciosek [21]). Considering the persistence and general stability of the known populations the status of $M$. linearis should be changed to naturalized plant, which follows the basic criteria mentioned by Richardson et al. [4,6]. However, the seemingly strict relationship of this species with fairly

\section{Acknowledgments}

We would like to express our gratitude to dr hab. Krzysztof Bińka for providing guidance and inestimable advice. The research was supported with statutory funds of the Department of Plant Ecology and Environmental Conservation of the Faculty of Biology, University of Warsaw.

\section{Authors' contributions}

The following declarations about authors' contributions to the research have been made: research designing, field research, conducting analyses of soil samples, writing the manuscript: ID; field research, writing the manuscript: $Ł K$; field research, conducting analyses of soil samples, text correction: PZ.

\section{Competing interests}

No competing interests have been declared.

\section{References}

1. European Environment Agency [Internet]. The impacts of invasive alien species in Europe. 2014 [cited 2014 Sep 14]; Available from: http:// www.eea.europa.eu/publications/impacts-of-invasive-alien-species

2. Pimentel D, McNair S, Janecka J, Wightman J, Simmonds C, O’Connell $\mathrm{C}$, et al. Economic and environmental threats of alien plant, animal, and microbe invasions. Agric Ecosyst Environ. 2001;84:1-20. http:// dx.doi.org/10.1016/S0167-8809(00)00178-X

3. Tokarska-Guzik B. The establishment and spread of alien plant species (kenophytes) in the flora of Poland. Katowice: Wydawnictwo intense anthropogenic influence (grassland management) leaves some doubts referring to the change of the status [5] and requires further observations of the species.

Montia linearis is a small, annual, predominantly autochoric plant without the ability of clonal spread. Due to the above-mentioned features its potential to become an invasive species was thought to be limited and it has not been considered invasive in Poland so far [36]. On the other hand our results are a proof of the species ability to survive, spread and form considerably stable populations thousands of kilometers from the species native range. The presented study showed that $M$. linearis could produce a large number of seeds and sometimes even dominated in herb communities. So far the species has inhabited only agricultural lands, however our research revealed its tolerance to a broad range of environmental conditions and proved its high reproductive potential. The aforementioned facts urge to consider it the intermediate risk species, which requires further observation (according to the scheme developed by Weber and Gut [37]). The observed ability of M. linearis to spread over relatively long distance $(>100 \mathrm{~m})$ in a short time period ( $<30$ years) also suggests that it can be reckoned as potentially invasive [4].

Undoubtedly, $M$. linearis requires further investigations in the known localities. Field explorations for this species are also recommended (in Poland and in other European countries). Due to the short life cycle, early flowering phenology and the small size of the species' individuals, $M$. linearis is relatively difficult to observe, especially in the dense meadow sward. Apart from the above-mentioned, research on soil seed bank, resistance to composting and potential pathways of dispersion of seeds of the species are needed to verify the status of M. linearis in Poland proposed within this study. Detailed investigations are essential in order to better control the species in case of its probable expansion.

Uniwersytetu Śląskiego; 2005. (Prace Naukowe Uniwersytetu Śląskiego w Katowicach; vol 2372).

4. Richardson DM, Pyšek P, Rejmánek M, Barbour MG, Panetta FD, West CJ. Naturalization and invasion of alien plants: concepts and definitions. Divers Distrib. 2000;6:93-107. http://dx.doi. org/10.1046/j.1472-4642.2000.00083.x

5. Tokarska-Guzik B, Dajdok Z, Zając M, Urbisz A, Danielewicz W. Identyfikacja i kategoryzacja roślin obcego pochodzenia jako podstawa działań praktycznych. Acta Bot Siles. 2011;6:23-53.

6. Richardson DM, Pyšek P, Carlton JC. A compendium of essential concepts and terminology in biological invasions. In: Richardson DM, editor. Fifty years of invasion ecology: the legacy of Charles Elton. Oxford: Blackwell Publishing; 2011. p. 409-420.

7. Tutin TG, Heywood VH, Burges NA, Moore DM, Valentine DH, Walters SM, et al., editors. Flora Europaea. Vol. 1: Lycopodiaceae to Platanaceae. Cambridge: Cambridge University Press; 1964.

8. Myers JH, Simberloff D, Kuris AM, Carey JR. Eradication revisited: dealing with exotic species. Trends Ecol Evol. 2000;15(8):316-320. http://dx.doi.org/10.1016/S0169-5347(00)01914-5

9. The Angiosperm Phylogeny Group. An update of the Angiosperm Phylogeny Group classification for the orders and families of flowering plants: APG III. Bot J Linn Soc. 2009;161:105-121. http://dx.doi. org/10.1111/j.1095-8339.2009.00996.x

10. Miller J. Montia. In: Flora of North America Editorial Committee, 
editors. Flora of North America North of Mexico. New York, NY: Oxford University Press; 2003. p. 485-488. (vol 4).

11. von Poellnitz K. Claytonia Gronov. und Montia Mich. Feddes Repert. 1932;30:279-325. http://dx.doi.org/10.1002/fedr.19320301704

12. Franklin JF, Dyrness CT. Natural vegetation of Oregon and Washington. Portland, OR: Oregon State University Press; 1988.

13. Hershkovitz MA. Montia linearis (Douglas) E. Greene (Portulacaceae) in Maryland. J Torrey Bot Soc. 1999;126(4):350-351. http://dx.doi. org/10.2307/2997319

14. Nilsson Ö. Studies in Montia L., Claytonia L., and allied genera. V. The genus Montiastrum (Gray) Rydb. Bot Notiser. 1971;124:87-121.

15. Rabeler RK, Bryson CT. Montia linearis (Portulacaceae), new to Mississippi. Sida. 1990;14:310-311.

16. Bińka K. Claytonia linearis Dougl. [Montia linearis (Dougl.) Greene] in Poland. Acta Soc Bot Pol. 1991;60:155-161. http://dx.doi.org/10.5586/ asbp. 1991.013

17. The PLANTS Database [Internet]. 2014 [cited 2014 May 15]; Available from: http://plants.usda.gov/core/profile?symbol=MOLI4

18. Lyshede OB, Petersen BV, Tranberg H. Årets fund 2002: øerne øst for Storebælt: nyt fra felten i Jylland: floristiske fund fra det fynske ørige. URT. 2003;27(1):3-15.

19. Danmarks Fugle og Natur [Internet]. Smalbladet vårportulak (Montia linearis). 2015 [cited 2015 Apr 10]; Available from: http://www.fugleognatur.dk/gallery.asp? mode=ShowLarge\&ID $=166147$

20. Jakab G, Molnár VA. A Montia linearis (Dougl.) Greene Magyarországon. Kitaibelia. 2005;10:121-127.

21. Ciosek MT. Claytonia linearis (Portulacaceae) w Wyszkowie (województwo mazowieckie). Fragm Florist Geobot Pol. 2001;8:281-282.

22. Gatunki obce w Polsce [Internet]. 2014 [cited 2014 May 15]; Available from: http://www.iop.krakow.pl/ias/gatunki/1557

23. Barkmann JJ, Doing H, Segal S. Kritische Bemerkungenund Vorschläge zur quantitativen Vegetationsanalyse. Acta Bot Neerl. 1964;13:394-419. http://dx.doi.org/10.1111/j.1438-8677.1964.tb00164.x

24. Mirek Z, Piękoś-Mirkowa H, Zając A, Zając M, editors. Flowering plants and pteridophytes of Poland - a checklist. Kraków. W. Szafer Institute of Botany, Polish Academy of Sciences; 2002. (Biodiversity of Poland; vol 1).

25. Hill MO, Bell N, Bruggeman-Nannenga MA, Brugués M, Cano MJ, Enroth J, et al. An annotated checklist of the mosses of
Europe and Macaronesia. J Bryol. 2006;28:198-267. http://dx.doi. org/10.1179/174328206X119998

26. Matuszkiewicz W. Przewodnik do oznaczania zbiorowisk roślinnych Polski. Warszawa: Wydawnictwo Naukowe PWN; 2008.

27. Ellenberg H, Weber HE, Düll R, Wirth V, Werner W, Paulissen D. Zeigerwerte von Pflanzen in Mitteleuropa. Göttingen: Goltze; 1991. (Scripta Geobotanica; vol 18).

28. Chytrý M, Pyšek P, Tichý L, Knollová I, Danihelka J. Invasions by alien plants in the Czech Republic: a quantitative assessment across habitats. Preslia. 2005;77: 339-354.

29. The European Network on Invasive Alien Species (NOBANIS) [Internet]. 2014 [cited 2014 Sep 25]; Available from: http://www.nobanis.org

30. Kershaw L, editor. Rare vascular plants of Alberta. Edmonton, AB: University of Alberta Press; 2001.

31. Pleasant J, Schlather KJ. Incidence of weed seed in cow (Bos sp.) manure and its importance as a weed source for cropland. Weed Technol. 1994;8:304-310.

32. Katovitch EJS, Becker RL, Doll J. Weed seed survival in livestock systems. USDA NRCS EQIP Edu. Assis. Grant prog. final report [Internet]. 2004 [cited 2014 Sep 10]; Available from: http://www. extension.umn.edu/agriculture/forages/pest/docs/umn-uw-ext-weedseed-survival-in-livestock-systems.pdf

33. Piechota T, Dach J. Zdolność kiełkowania diaspor chwastów przechowywanych w oborniku kompostowanym z napowietrzaniem i w warunkach składowania beztlenowego. Ann Univ Mariae CurieSkłodowska E Agric. 2007;62(2):177-184.

34. Albrecht MA, Penagos ZJC. Seed germination ecology of three imperiled plants of rock outcrops in the southeastern United States. J Torrey Bot Soc. 2012;139(1):86-95. http://dx.doi.org/10.3159/ TORREY-D-11-00066.1

35. Urbisz A. Occurrence of temporarily-introduced alien plant species (ephemerophytes) in Poland - scale and assessment of the phenomenon. Katowice: Wydawnictwo Uniwersytetu Śląskiego; 2011. (Prace Naukowe Uniwersytetu Śląskiego w Katowicach; vol 2897).

36. Tokarska-Guzik B, Dajdok Z, Zając M, Zając A, Urbisz A, Danielewicz W, et al. Rośliny obcego pochodzenia w Polsce ze szczególnym uwzględnieniem gatunków inwazyjnych. Warszawa: Generalna Dyrekcja Ochrony Środowiska; 2012.

37. Weber E, Gut D. Assessing the risk of potentially invasive plant species in Central Europe. J Nat Conserv. 2004;12:171-179. http://dx.doi. org/10.1016/j.jnc.2004.04.002 